\title{
EXPERIMENTAL BEHAVIOR OF PRECAST PRESTRESSED HOLLOW CORE SLABS STRENGTHENED WITH DIFFERENT TECHNIQUES
}

\author{
M. A. Kandil, N. N. Meleka, M. A. Tayel \\ Department of Civil Engineering, Faculty of Engineering \\ Menoufia University, Egypt
}

ABSTRACT

Precast prestressed hollow-core reinforced concrete slabs are used extensively for floor and roofing systems in precast concrete construction. This paper investigates reinforced concrete precast prestressed hollow core slabs strengthened with different systems. An experimental test program prepared to test some models of precast prestressed reinforced concrete hollow core slabs before and after strengthening. Nine full-scale hollow core slabs having the dimensions 4100x1200x160 mm were tested. Specimens were classified in three groups. The first group contains two control specimens tested without any strengthening. Second group contains three specimens strengthened by using GFRP strips. Third group contains four specimens strengthened by using steel plates. All slabs were tested under two central the line loads at middle third of span until failure. Test results showed that all of the strengthening techniques are very effective in increasing the element's structural carrying capacity.

Keywords: Strengthening; Precast, Prestressed; Hollow core slab; Steel plates; GFRP.

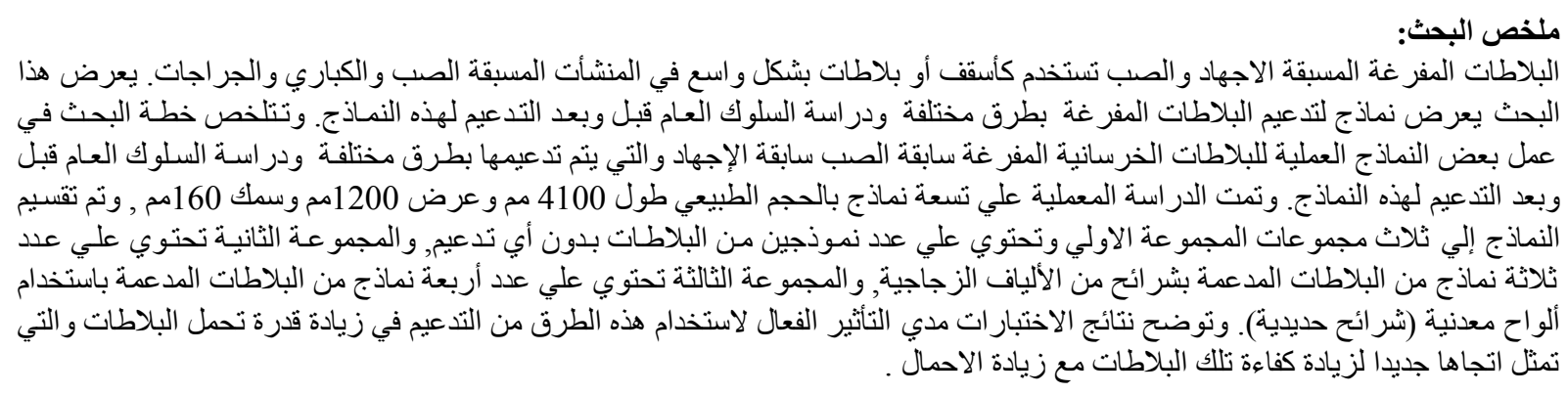

\section{INTRODUCTION}

Hollow Core Slabs are prestressed concrete elements that are cast with advanced extrusion technique to be used as floor and roof deck system, partitions walls, as well as boundary wall panels. The primary purpose of the cores/voids running through the slabs continuously is to decrease the weight and materials within the floor, yet maintaining the maximal strength. These voids also offer the possibility to be used as service ducts for concealed services such as plumbing and electrical works. They can even be used as ducts for air conditioning. Building systems using hollow core slabs have proven to be effective and efficient in residential buildings, schools, bridges, car parks, multi-story buildings and multi-purpose centers [1-4].

Precast prestressed hollow core (PPHC) slabs are widely used in concrete or composite floor structures in buildings. Because of their excellent structural performance at room temperature, advanced manufacturing methods, and low-cost installation, PPHC slabs have an important market presence in many countries. Prestressed reinforcement improves the serviceability performance of PPHC slabs compared to plain slabs (those without voids), increasing the cracking moment as well as the loadbearing capacity. Span lengths of up to $16 \mathrm{~m}$ and high load levels can be achieved with PPHC slab floor systems. PPHC slabs must be installed in different ways depending on the support conditions and desired behavior of the floor structure. There are constructive arrangements compatible with in-situ concrete beams, precast concrete beams (I-sections, reversed $\mathrm{T}$ sections), and steel beams, all of them with or without topping (i.e., upper concrete layer) $[5,6]$.

It is possible for most buildings of various types such as commercial, residential and industrial to be designed for construction in precast concrete. Buildings with high degree of modular coordination and repetitive structural grids are ideal for precast construction. Even buildings with irregular layout are often suitable for partial precast construction. It is common misconception that precast concrete lacks flexibility. With creativity and standardization of basic precast elements, details and connections, a wide variety of plans, elevations, and features can be achieved with precast concrete [7]

There are a number of situations where it may become necessary to repair and/or strengthening of the 
reinforced concrete structures. The situations in which the reinforced concrete structures require the intervention for repairs or strengthening are the following: Limiting crack width under increased service loads, changing in the structural system such as cut-outs in the existing reinforced concrete structures, changes of the design parameters, rectifying design and construction errors such as undersized reinforcement, optimization of structure regarding the reduction of deformations and of the stresses in the reinforcing bars, and retrofitting concrete members to enhance the flexural strength and strain to failure of concrete elements requested by increased loading conditions such as earthquakes or traffic loads [8,9].

There are several strengthening methods have been used in the past with varying degrees of success to increase the capacity of the existing structures. These methods include: Reduction of span length, increasing of the cross section, addition of new steel members, steel plate bonding, external post-tensioning, and external bonding with FRP plate [9-15]

Strengthening by means of fiber reinforced polymers (FRP) has been widely used and investigated in the last few decades. The ease of handling and application gives FRP sheets an advantage over the traditional strengthening techniques [15-21], and some recommendations are included in the first design guidelines for strengthened concrete. ACI 440.2R-08 [22].

\section{EXPERIMENTAL PROGRAM}

\subsection{Test specimens}

Full-scale load test was conducted on nine precast prestressed hollow-core slabs obtained from a local precast manufacturer factory (Modern Concrete for Precast and Prestressed Members) at Sadat city; Table 1 shows details of the Tested Specimens. All specimens have a total length of $4100 \mathrm{~mm}$ and clear span of $4000 \mathrm{~mm}$, a depth of $160 \mathrm{~mm}$ and a width of $1200 \mathrm{~mm}$. The first group contains two specimens $\mathrm{CO} 1$ and $\mathrm{CO} 2$. They are considered as control specimens. Fig. 1 shows the cross section of the control specimen. The second group contains three specimens strengthened using GFRP warps; S4G2L, S4G4L, and S2G4L. S4G2L is strengthened by using four strips of $100 \mathrm{~mm}$ width; each strip consists of two layers as shown in Fig. 2 and S4G4L is strengthened by using four strips of $100 \mathrm{~mm}$ width, each strip consists of four layers. S2G4L strengthened by using four layers of GFRP wraps (two strips $200 \mathrm{~mm}$ width) as shown in Fig. 3. The third group contains four specimens S4ST2, S4ST3, S2ST2, and S2ST3. S4ST2 strengthened by using steel plates $2.0 \mathrm{~mm}$ thickness (four strips, each $100 \mathrm{~mm}$ width), as shown in Fig. 4 and S4ST3 strengthened by using steel plates $3.0 \mathrm{~mm}$ thickness (four strips, each $100 \mathrm{~mm}$ width), S2ST2 strengthened by using steel plates $2.0 \mathrm{~mm}$ thickness (two strips, each $200 \mathrm{~mm}$ width) as shown in Fig. 5 and S2ST3 strengthened by using steel plates $3.0 \mathrm{~mm}$ thickness (two strips, each $200 \mathrm{~mm}$ width).

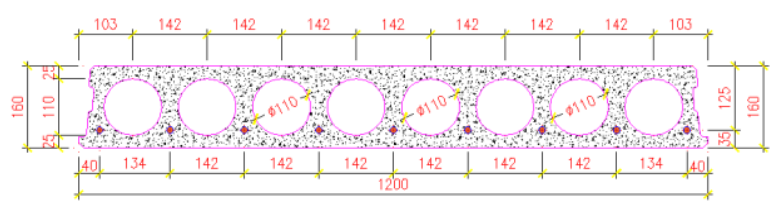

Fig. 1: Geometry of PPHC control slab

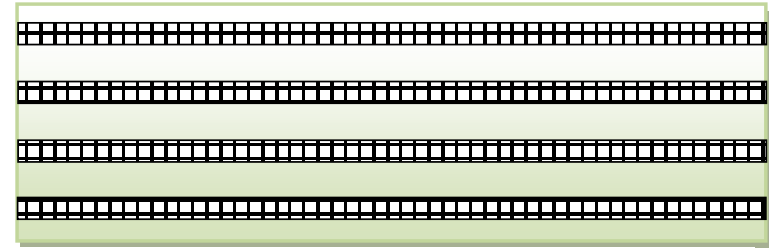

Fig. 2: Typical plan for specimens S4G2L, and S4G4L strengthened by four strips

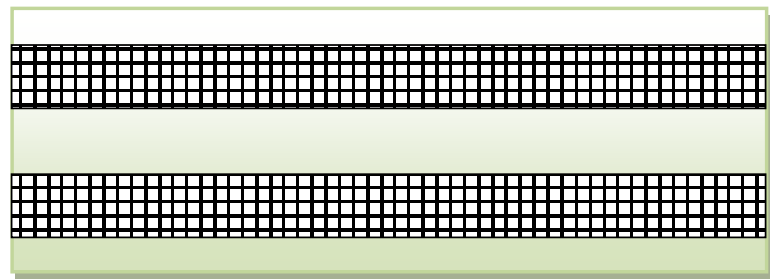

Fig. 3: Typical plan for specimen S2G4L strengthened by two strips

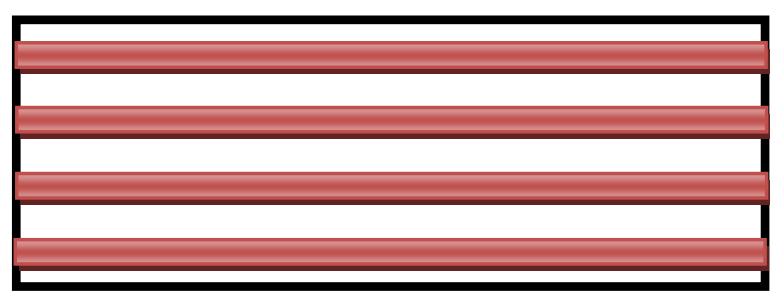

Fig. 4: Typical plan for specimens S4ST2, and S4ST3 strengthened by four strips

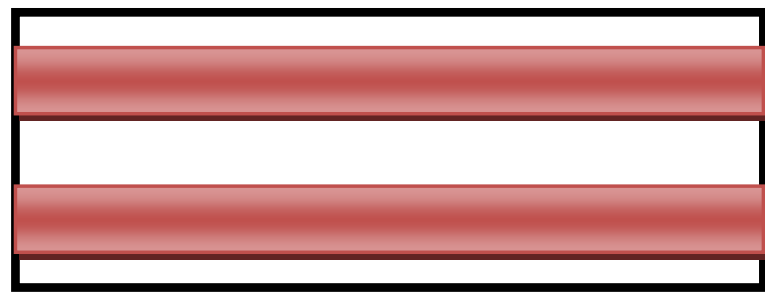

Fig. 5: Typical plan for specimen S2ST2, and S2ST3 strengthened by two strips 
Table 1. Details of the Tested Specimens

\begin{tabular}{|c|c|c|l|l|}
\hline $\begin{array}{c}\text { Group } \\
\text { No. }\end{array}$ & $\begin{array}{c}\text { Slab } \\
\text { Code }\end{array}$ & $\begin{array}{c}\text { No. of } \\
\text { slabs }\end{array}$ & Conditions & \multicolumn{1}{|c|}{ Strengthening system } \\
\hline Group 1 & CO & 2 & Control & Control slab (without strengthening) \\
\hline \multirow{4}{*}{ Group 2 } & S4G4L & 1 & Strengthening & $\begin{array}{l}\text { Strengthening by using four layers of GFRP wraps (Four } \\
\text { strips 100 mm width) (Fig. 2). }\end{array}$ \\
\cline { 2 - 6 } & S2G4L & 1 & Strengthening & $\begin{array}{l}\text { Strengthening by using four layers of GFRP wraps (two } \\
\text { strips 200 mm width) (Fig. 3). }\end{array}$ \\
\hline & S4ST2 & 1 & Strengthening & $\begin{array}{l}\text { Strengthening by using steel plates 2.0 mm thickness (Four } \\
\text { strips 100 mm width) (Fig. 4). }\end{array}$ \\
\cline { 2 - 6 } & S4ST3 & 1 & Strengthening & $\begin{array}{l}\text { Strengthening by using steel plates 3.0 mm thickness (Four } \\
\text { strips 100 mm width) (Fig. 4). }\end{array}$ \\
\cline { 2 - 6 } Group 3 & S2ST2 & 1 & Strengthening & $\begin{array}{l}\text { Strengthening by using steel plates 2.0 mm thickness (Two } \\
\text { strips 200 mm width) (Fig. 5). }\end{array}$ \\
\cline { 2 - 5 } & S2ST3 & 1 & Strengthening & $\begin{array}{l}\text { Strengthening by using steel plates 3.0 mm thickness (Two } \\
\text { strips 200 mm width) (Fig. 5). }\end{array}$ \\
\hline
\end{tabular}

\subsection{Material properties}

\subsubsection{Concrete}

All the prestressed precast PPHC slabs were manufactured in the precast factory (Modern Concrete for Precast and Prestressed Members) at Sadat city. Cement content of the mixture $400 \mathrm{~kg} / \mathrm{m}^{3}$, w/c ratio equal to 0.25 . Low w/c was achieved by using sikament-163M. The average 28-day cube compressive strength of the used concrete was $50 \mathrm{MPa}$. The unit weight was about $24.0 \mathrm{kN} / \mathrm{m}^{3}$.

\subsubsection{Prestressing strands}

Each slab has nine longitudinal prestressed strands (One strand per web). Uncoated bright steel 7-wire P.C. strand (9.3 mm nominal diameter) low- relaxation strands were used. Coupon tests were conducted and the average ultimate tensile strength and modulus of elasticity were found to be $1,860 \mathrm{MPa}$ and $200 \mathrm{GPa}$; respectively.

\subsubsection{Steel plates:}

Yield stress, tensile strength, and modulus of elasticity were $240 \mathrm{MPa}, 350 \mathrm{MPa}$, and $2 \times 10^{5} \mathrm{MPa}$ respectively.

\subsubsection{GFRP layers:}

Glass fiber reinforced polymer wraps were used for strengthening. The tensile strength and modulus of elasticity were found to be $300 \mathrm{MPa}$, and $21000 \mathrm{MPa}$; respectively.

\subsection{Test setup}

The specimens were tested as simply supported slab under two lines loads at middle third of span as illustrated in Fig.6. A 500 kN hydraulic jack was used to apply the load which was transferred to the slab using a rigid longitudinal spreader beam. Two transverse I beams were used for applying uniformly distributed line loads along the width of slabs. The supports and the loading system were sufficiently stiffened to avoid any local buckling. The load was applied gradually for the tested specimens in the experimental program with a constant value equal to $5.00 \mathrm{kN}$ per increment. At the end of each increment, deflections were measured and crack patterns were marked. Cracking and ultimate failure loads were defined. The instrumentation and the test set up is shown in Fig.7.

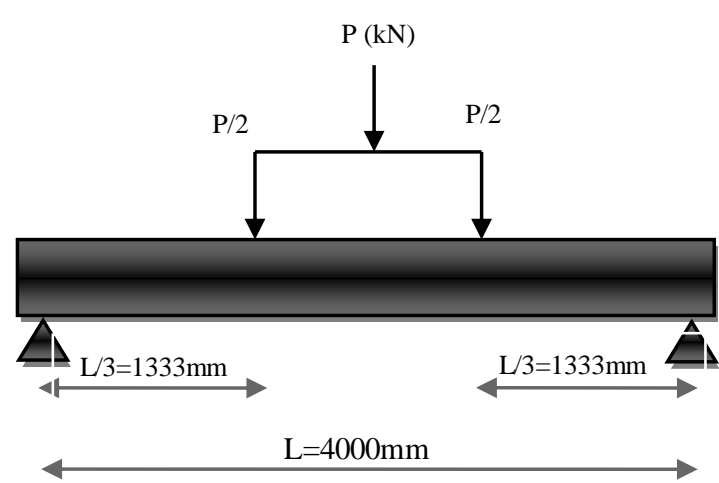

Fig. 6: Schematics of experimental test 


\subsubsection{Measuring Devices}

Three mechanical dial gauges with accuracy $50 \mathrm{~mm}$ and $25 \mathrm{~mm}$ were installed to measure the deflections at different points of the tested slab. One dial gauge was placed at mid-span, and two dial gauges were placed under line loads to measure deflection. The testing equipment and the test setup are shown in Fig.7.

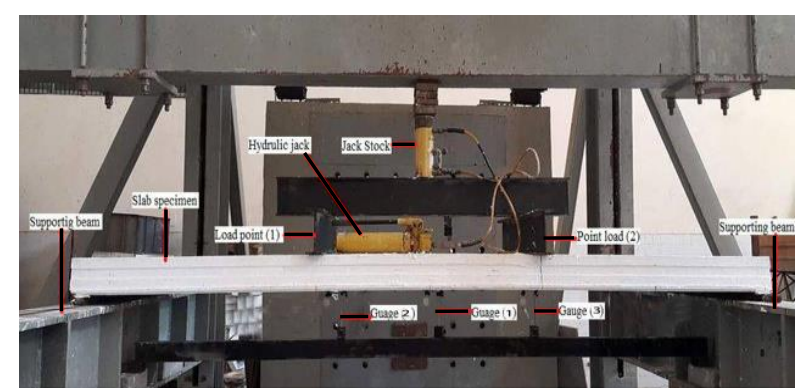

Fig. 7: Test setup and instrumentations

\section{RESULTS AND DISCUSSION}

\subsection{Load deflection behavior}

Load deflection curves of the control slab in the first group at mid of span and under line load are presented in Fig.8. The load deflection curve for control slab $\mathrm{CO} 2$ shows a typical under-reinforced behavior for bending stresses. The slab was cracked in flexure at the bottom fiber after the tensile strength of concrete had reached. Cracking was reflected through a change in slope of the load-displacement curve. With further increase in the applied load, strands started resisting the load until their yielding. Soon after the yielding of the strands, load displacement curve flattened and no further increase in load resistance was observed. The ultimate failure load for slab $\mathrm{CO} 2$ was about $135 \mathrm{kN}$ and the corresponding maximum deflection was about $54.5 \mathrm{~mm}$.

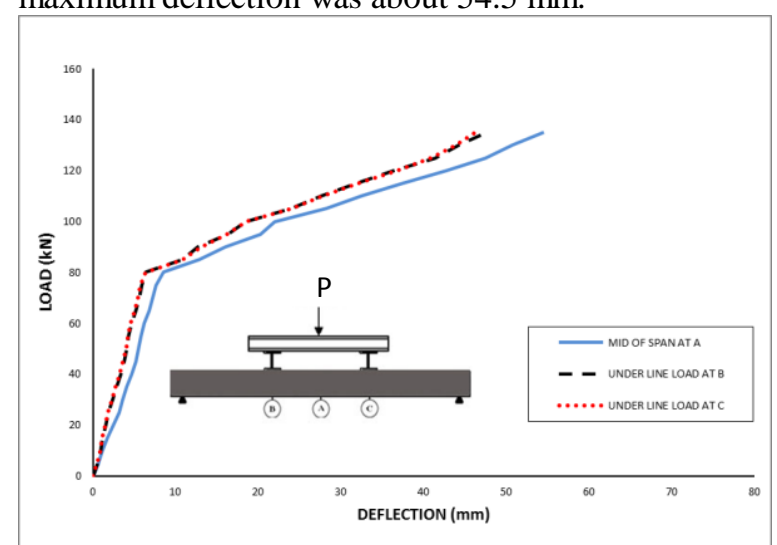

Fig. 8: Load-Deflection curve for $\mathrm{CO} 2$ slab

For the second group load deflection curves shows behavior of PPHC slabs with strengthening by using two and four layers of GFRP. Comparison of load deflection behavior for specimens S4G2L, S4G4L, and
S2G4L at mid of span and under line load are shown in Figs. 9 and 10 respectively. \{For S4G2L has registered maximum deflection $57.9 \mathrm{~mm}$ at ultimate load $145 \mathrm{kN}, \mathrm{S} 4 \mathrm{G} 4 \mathrm{~L}$ has registered maximum deflection $59.8 \mathrm{~mm}$ at ultimate load $160 \mathrm{kN}$, and S2G4L has registered maximum deflection $69.6 \mathrm{~mm}$ at ultimate load $155 \mathrm{kN}$ \}. It is noted that $\mathrm{S} 4 \mathrm{G} 4 \mathrm{~L}$ which strengthened by using four layers of GFRP wraps (Four strips $100 \mathrm{~mm}$ width) has registered the smallest values in deflections at the same load.

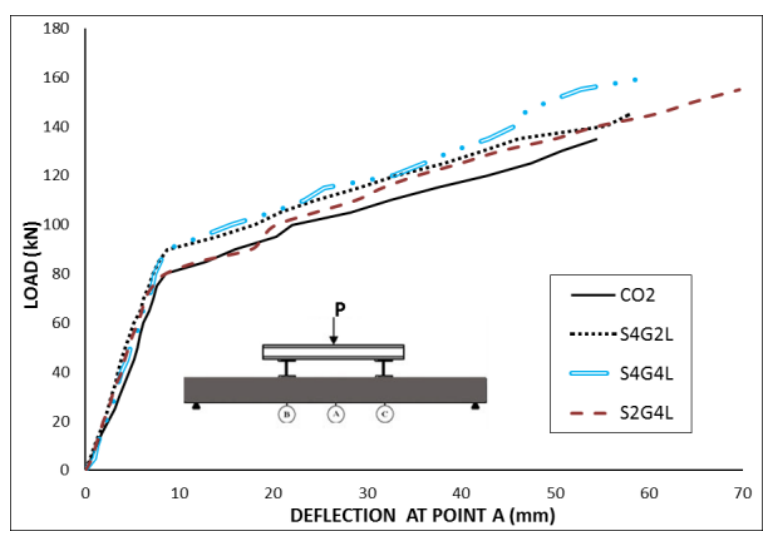

Fig. 9: Load-Deflection curves at mid-span for CO2, S4G2L, S4G4L, and S2G4L

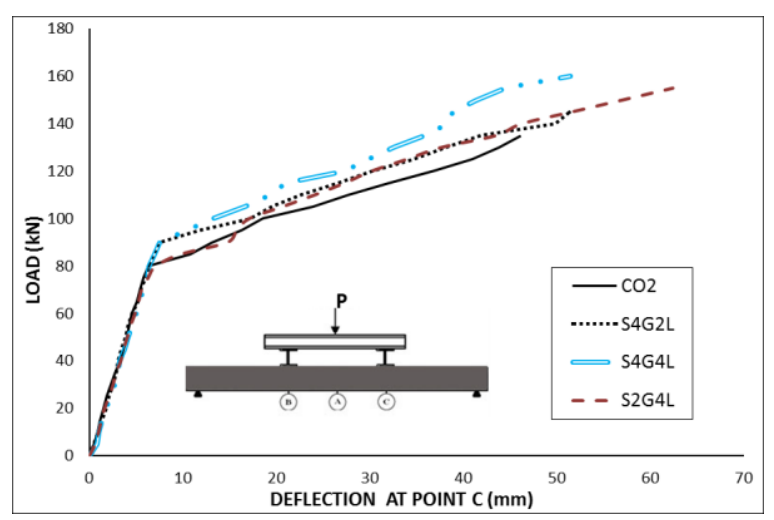

Fig. 10: Load-Deflection curves at underline load for CO2, S4G2L, S4G4L, and S2G4L

For the third group, load deflection curves compare the behavior of strengthened PPHC slabs by steel plates. Comparison of load deflection behavior between S4ST2, S4ST3, S2ST2 and S2ST3 at mid of span and under line load are shown in Figs. 11 and 12 respectively. \{For S4ST2 has registered maximum deflection $79.3 \mathrm{~mm}$ at ultimate load $200 \mathrm{kN}$, S4ST3 has registered maximum deflection $55.6 \mathrm{~mm}$ at ultimate load $215 \mathrm{kN}$, S2ST2 has registered maximum deflection $60.1 \mathrm{~mm}$ at ultimate load $190 \mathrm{kN}$, and S2ST3 has registered maximum deflection $49.3 \mathrm{~mm}$ at ultimate load $200 \mathrm{kN}$. Also it is noted that S4ST3 which Strengthened by using steel plates $3.0 \mathrm{~mm}$ thickness Four strips $100 \mathrm{~mm}$ width has registered the smallest values in deflections at the same load. 


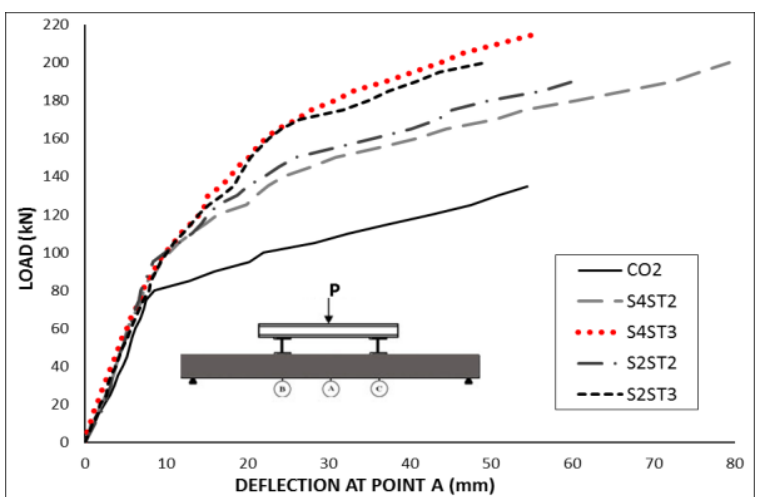

Fig. 11: Load-Deflection curves at mid-span for CO2, S4ST2, S4ST3, S2ST2, and S2ST3

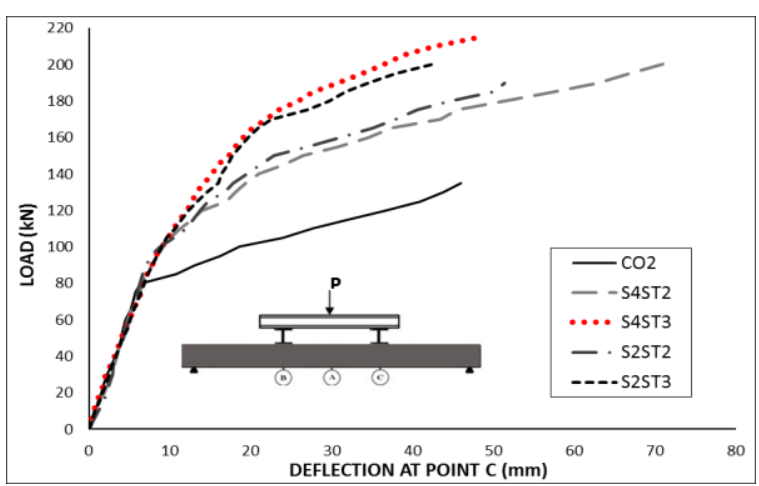

Fig. 12: Load-Deflection curves at underline load for CO2, S4ST2, S4ST3, S2ST2, and S2ST3

Comparisons of load deflection behavior obtained between all PPHC slabs at mid of span and under line load are shown in Figs. 13 and 14 respectively. And the summarized test results shown in Table 2.

Table 2. Test results

\begin{tabular}{|c|c|c|c|c|}
\hline $\begin{array}{c}\text { Slab } \\
\text { code }\end{array}$ & $\begin{array}{c}\text { Cracking } \\
\text { load } \\
\text { (Pcr) } \mathrm{kN}\end{array}$ & $\begin{array}{c}\text { Ultimate } \\
\text { failure } \\
\text { load } \\
(\mathrm{Pu}) \mathrm{kN}\end{array}$ & $\begin{array}{c}\text { MAX } \\
\text { DEF. } \\
(\mathrm{mm})\end{array}$ & $\begin{array}{c}\text { Increase in } \\
(\mathrm{Pu}) \\
\text { comparing } \\
\text { with CO\% }\end{array}$ \\
\hline CO2 & 80 & 135 & 54.5 & ----- \\
\hline S4G2L & 90 & 145 & 57.9 & $7.0 \%$ \\
\hline S4G4L & 90 & 160 & 59.8 & $19.0 \%$ \\
\hline S2G4L & 85 & 155 & 69.6 & $15.0 \%$ \\
\hline S4ST2 & 100 & 200 & 79.3 & $48.0 \%$ \\
\hline S4ST3 & 105 & 215 & 55.6 & $59.0 \%$ \\
\hline S2ST2 & 100 & 190 & 60.1 & $41.0 \%$ \\
\hline S2ST3 & 100 & 200 & 49.3 & $48.0 \%$ \\
\hline
\end{tabular}

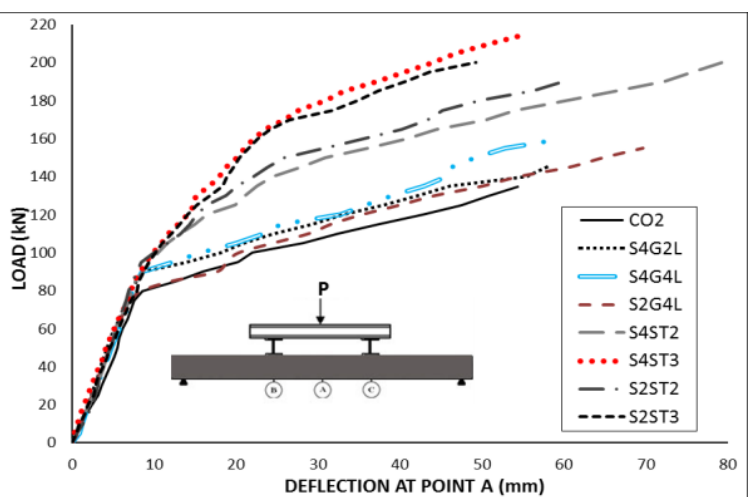

Fig. 13: Load-Deflection curves at mid-span for tested slabs

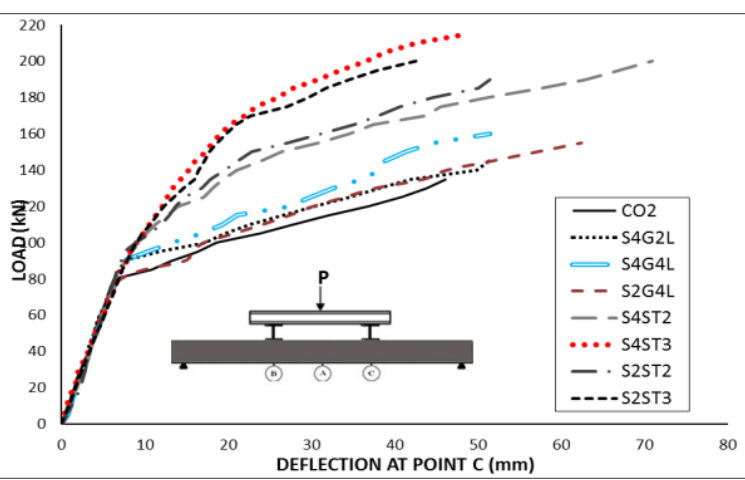

Fig. 14: Load-Deflection curves at underline load for tested slabs

\subsection{Cracking and failure mode}

Fig. 15 shows comparison between cracking and ultimate loads for all tested PPHC Slabs. It was noted that the initial cracking load and ultimate failure load for PPHC slabs were as shown in table 1. Referring to $\mathrm{CO} 2$ the initial cracking load for slabs S4G2L, S4G4L, S2G4L, S4ST2, S4ST3, S2ST2 and S2ST3 increased by about 13\%, 13\%, 6\%, 25\%, 31\%, 25\%, and $25 \%$ respectively. And the ultimate failure load increased by about 7\%, 19\%, 15\%, 48\%, 59\%, 41\%, and $48 \%$ respectively. It is noticed that using steel strips for strengthening the PPHC slabs increases the flexural capacity more than strengthening by GFRP layers.

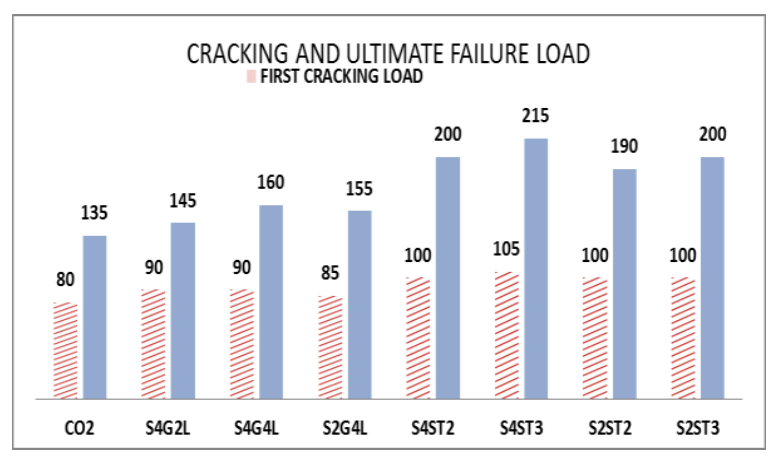

Fig. 15: Comparison between cracking and ultimate failure loads for the tested PPHC slabs 
More distributed cracks were formed with further increase in loads along the length of specimen as shown in Figs. (16-23). Significant displacement ductility was observed at the failure indicating an under reinforced failure mode.

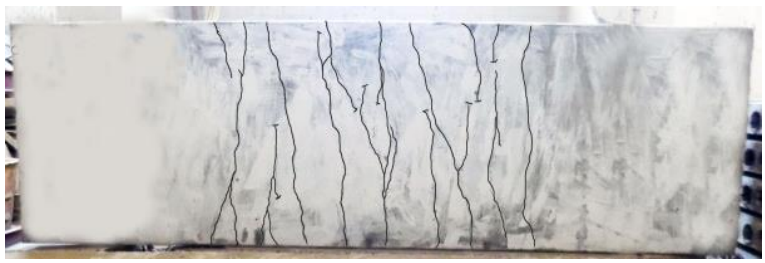

Fig. 16: Cracks pattern for $\mathrm{CO} 2$ at $\mathrm{p}=135 \mathrm{kN}$

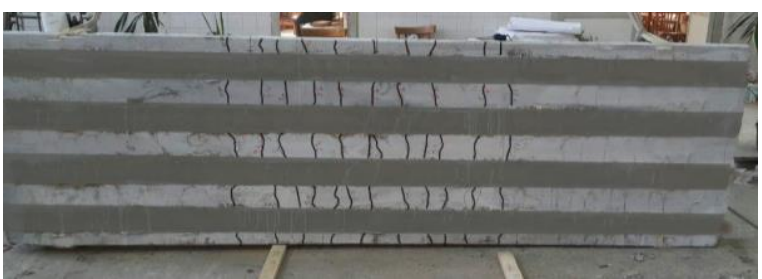

Fig. 17: Cracks pattern for $S 4 G 2 L$ at $p=145 \mathrm{kN}$

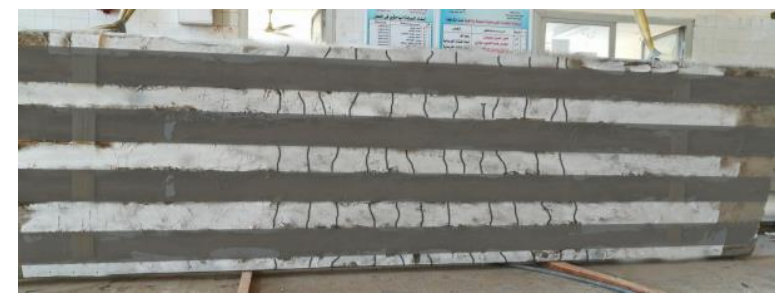

Fig. 18: Cracks pattern for $\mathrm{S} 4 \mathrm{G} 4 \mathrm{~L}$ at $\mathrm{p}=160 \mathrm{kN}$

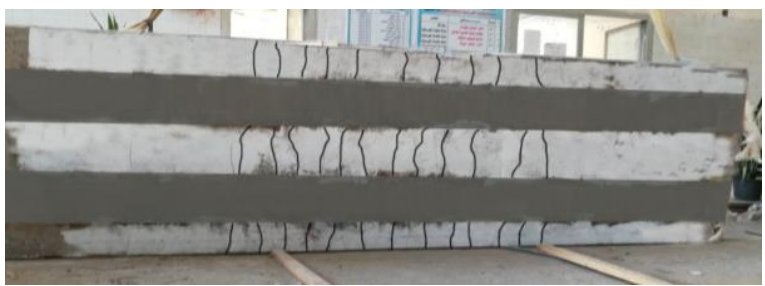

Fig. 19: Cracks pattern for $S 2 G 4 L$ at $p=155 \mathrm{kN}$

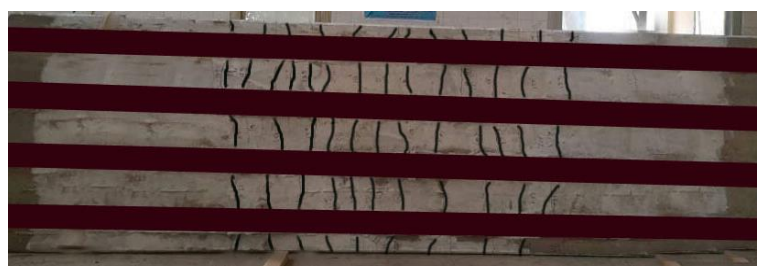

Fig. 20: Cracks pattern for $S 4 S T 2$ at $p=200 \mathrm{kN}$

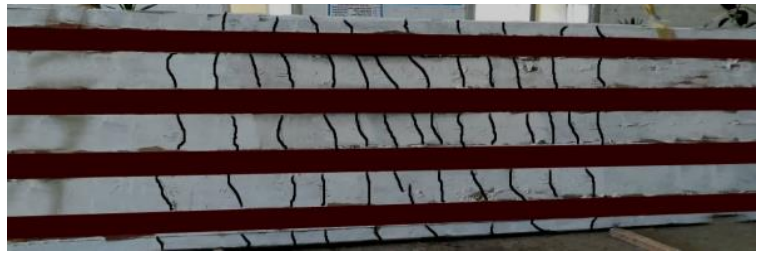

Fig. 21: Cracks pattern for S4ST3 at $p=215 \mathrm{kN}$

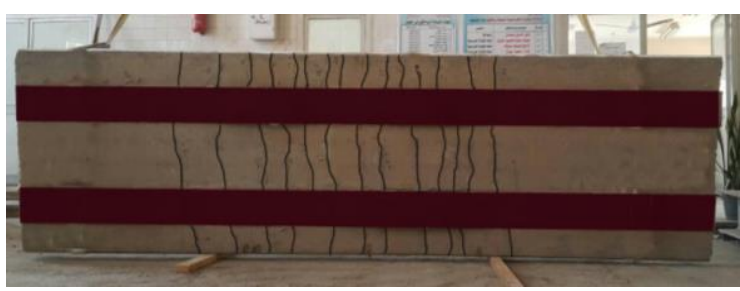

Fig. 22: Cracks pattern for S2ST2 at $p=190 \mathrm{kN}$

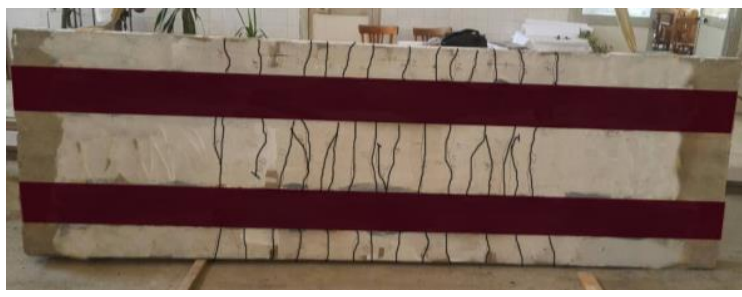

Fig. 23: Cracks pattern for S2ST3 at $p=200$

\section{CONCLuSions}

Full scale tests were carried out to investigate the structural behavior and capacity of PPCH slabs with and without strengthening. Conclusions could be drawn as follows:

1-Load - deflection curves of all PPHC slabs at different locations were linear till first cracking load. After cracking, deflections increased rapidly as the load increased.

2-Strengthening with steel plates has a clear effect on the flexural capacity of PPHC slabs. Using steel strips for strengthening the PPHC slabs increases the flexural capacity more than strengthening by GFRP layers.

3- Using four strips $100 \mathrm{~mm}$ width to strengthen the PPHC slabs gave better than using two strips 200 $\mathrm{mm}$ width for the same technique.

4- Strengthening with steel plates $3.0 \mathrm{~mm}$ thickness using four strips $100 \mathrm{~mm}$ width to strengthen the PPHC slabs was the best technique suggested in this study, which has the highest results in the cracking load and ultimate load. In addition to have the lowest value in deflection at the same load.

5- Strengthening process using both GFRP and steel strips reduces the presence of cracks and decreases in crack width. 


\section{REFERENCES}

[1] U. A. Girhammar and M. Pajari, "Tests and analysis on shear strength of composite slabs of hollow core units and concrete topping," Constr. Build. Mater., Vol. 22, No. 8, pp. 1708-1722, 2008.

[2] Cuenca, E., and P. Serna. "Failure modes and shear design of prestressed hollow core slabs made of fiber-reinforced concrete." Composites Part B: Engineering 45, No. 1 (2013): 952-964.

[3] J. V. Aguado, A. Espinos, A. Hospitaler, J. Ortega, and M. L. Romero, "Influence of reinforcement arrangement in flexural fire behavior of hollow core slabs," 2012.

[4] K. M. Monisha and G. Srinivasan, "Experimental behavior of prestress hollow core slab, RC hollow core slab and normal RC solid slab," International Research Journal of Engineering and Technology, Vol. 4, pp. 1090-1093, 2017.

[5] J. V. Aguado, V. Albero, A. Espinos, A. Hospitaler, and M. L. Romero, “A 3D finite element model for predicting the fire behavior of hollowcore slabs," Engineering Structures, Vol. 108, pp. 12-27, 2016.

[6] V. S. Sreejith, and M. Sirajuddin "Flexural beahavior of prestressed hollow slab," International Journal of Civil Engineering and Technology (IJCIET), Vol. 8, No. 3, pp. 90-99, 2017

[7] Construction Industry Development Board, "Guide to Precast Concrete and Prefabricated Reinforcement for Buildings.”, Singapore. Construction Industry Development Board, 1997

[8] Khalid Heiza, Ahmed Nabil, Nageh Meleka, and Magdy Tayel. "State-of-the Art Review: Strengthening of Reinforced Concrete StructuresDifferent Strengthening Techniques." In Sixth International Conference on Nano-Technology in Construction, 22-24 March 2014.

[9] Foubert, Steven, Karam Mahmoud, and Ehab ElSalakawy. "Behavior of Prestressed Hollow-Core Slabs Strengthened in Flexure with Near-Surface Mounted Carbon Fiber-Reinforced Polymer Reinforcement." Journal of Composites for Construction 20, No. 6 (2016).

[10] F. Elgabbas, A. A. El-Ghandour, A. A. Abdelrahman, and A. S. El-Dieb, "Different CFRP strengthening techniques for prestressed hollow core concrete slabs: Experimental study and analytical investigation," Journal of Composite Structures, Vol. 92, No. 2, pp. 401-411, 2010.
Pimanmas, "A. Finite element analysis of FRPstrengthened RC beams", Songklanakarin J. Sci. Technol., Vol: 26 No. 4. (2004) PP.497-507.

[12] Ola Enochsson. CFRP Strengthening of Concrete Slabs, with and without Openings Experiment, Analysis, Design and Field Application, Licentiate Thesis. 2005. LULEA University of Technology.

[13] X.Z. Lu, J.F. Chen, L.P. Ye, J.G. Teng, and J.M. Rotter. RC beams shear-strengthened with FRP: Stress distributions in the FRP reinforcement. Construction and Building Materials. (2008).

[14] Rob Irwin and Amar Rahman. FRP strengthening of concrete structures - design constraints and practical effects on construction detailing. 2002.

[15] An Introduction to FRP Strengthening of Concrete Structures. ISIS Educational Module 4, 2004.

[16] Oualid Limam, Gilles Foret, and Alain Ehrlacher. RC two-way slabs strengthened with CFRP strips: experimental study and a limit analysis approach. Composite Structures. 60 (2003) 467-471.

[17] Ayman S. Mosallam, Khalid M. Mosalam. Strengthening of two-way concrete slabs with FRP composite laminates. Construction and Building Materials. 17 (2003) 43-54.

[18] Tounsi Abdelouahed. Improved theoretical solution for interfacial stresses in concrete beams strengthened with FRP plate. International Journal of Solids and Structures. 43 (2006) 4154-4174.

[19] H.A. Abdalla, A.M. Torkey, H.A. Haggag, and A.F. Abu Amira. Design against cracking at openings in reinforced concrete beams strengthened with composite sheets. Composite Structures. 60 (2003) 197-204.

[20] Osman Hag-Elsafi, Sreenivas Alampalli, and Jonathan Kunin. Application of FRP laminates for strengthening of a reinforced concrete T-beam bridge structure. Composite Structures. 52 (2001) 453-466.

[21] F. Ceroni. Experimental performances of RC beams strengthened with FRP materials. Construction and Building Materials. 24 (2010) 1547- 1559 .

[22] American Concrete Institute (ACI). Guide for the design and construction of externally bonded FRP systems for strengthening of concrete structure. ACI 440.2R-08. Mich.: Farmington Hill; 2008.

[11] Supaviriyakit, T., Pornpongsaroj, P. and 